\title{
Gross anatomy of the stomach of the pampas deer, Ozotoceros bezoarticus (Artiodactyla: Cervidae)
}

\author{
William Perez ${ }^{1,3} \&$ Rodolfo Ungerfeld ${ }^{2}$
}

\author{
1 Área de Anatomía, Facultad de Veterinaria, Universidad de la República. Lasplaces 1620, 11600 Montevideo, Uruguay. \\ 2 Departamento de Fisiología, Facultad de Veterinaria, Universidad de la República. Lasplaces 1620, 11600 Montevideo, \\ Uruguay \\ ${ }^{3}$ Corresponding author. E-mail: vetanat@gmail.com
}

\begin{abstract}
The macroscopic anatomy of the stomach of the adult pampas deer, Ozotoceros bezoarticus (Linnaeus, 1758), a cervid species considered to ingest high quantities of grass in its natural diet, was described. Fourteen deceased adult pampas deer of both sexes from a captive breeding station were used for this study. There were no differences in the absolute or relative size from the different compartments of the stomach in relation to gender. Compared to measurements in other ruminants, pampas deer appeared anatomically capable of feeding on a variety of diets as an 'intermediate feeder'.
\end{abstract}

KEY WORDS. Abdomen; abomasums; cervidae; forestomach; ruminant.

The pampas deer, Ozotoceros bezoarticus (Linnaeus, 1758) was a wide-ranging species, originally distributed in the open grasslands (pampas) across eastern South America, from $5^{\circ}$ to $41^{\circ} \mathrm{S}$ (JACKSON \& LANGGUTH 1987). However, loss of habitat, unregulated hunting, competition with cattle (JACKSON \& GiULLIETI 1988), and transmission of diseases from cattle (Jungius 1976) have caused a drastic decrease in pampas deer populations. The species is considered as Near Threatened by the IUCN (GonzÁLEZ \& Merino 2008), with small populations reported in Argentina, Brazil and Uruguay.

The ruminants are classified into three groups according to their feeding types: browsers, intermediate feeders, and grazers. This classification has been linked to anatomical studies of mainly African, European, and North American species (HofmanN \& Stewart 1972, Hofmann 1973, 1989). Browser ruminants eat predominantly woody and non-woody dycotyledonous forage, for instance tree foliage, herbs, or wild fruits - e.g., Alces alces (Linnaeus, 1758) and Giraffa camelopardalis (Linnaeus, 1758). On the other hand, grazer ruminants - e.g., Syncerus cafer (Sparrman, 1779) and Ovis aries (Linnaeus, 1758) - feed on graminaceous plants. Intermediate feeders consume monocotyledonous forage - i.e., grasses - to a certain degree, but for some species this depends mostly on seasonal variation of availability - e.g., Taurotragus oryx (Pallas, 1766) and Rupicapra rupicapra (Linnaeus, 1758) (Hofmann \& Stewart 1972, Hofmann 1973, 1988, 1989).

Hofmann $(1973,1988,1989)$ reported that there are three categories of morphological variation of the digestive tract: grazing, browsing, and intermediate types (named for the feeding strategies used). He subsequently suggested hypotheses for consequent physiological differences. In the grazer category, the mucosa of the dorsal rumen is unpapillated; the mucosa of the rumen is unpapillated with strong pillars and pronounced reticular crests with secondary and tertiary crests; and the omasum is comparatively large with four orders of laminae. Typical characteristics of ruminants in the browser category are evenly distributed ruminal papillae, papillated rumen pillars, a large reticulum with low reticular crests, and a small omasum (Hofmann 1973, 1988, 1989, Clauss et al. 2006a,b, 2009a,b,c, 2010a,b). With respect to ecological niche partitioning among ruminants, the length ratio of the small intestine to the large intestine is 1.9-2.7 in browser ruminants, and 4.04.5 in grazer ruminants (Hofmann 1989).

Less is known about South American species. With respect to feeding types, the pampas deer seems to be peculiar among cervids. Most cervids are considered to be either browsers or intermediate feeders that do not feed on large quantities of grass (Hofmann 1985). There are a few species, however, such as the Père Davids deer, Elaphurus davidianus (Milne-Edwards, 1866), and the pampas deer, that consume comparatively large quantities of grasses in its natural diet (JACKSON et al. 1980, JACKSON \& GUILIETTI 1988). Cosse et al. (2009) considered the pampas deer to be an opportunistic species based on their foraging behavior, which was typical of an intermediate feeder. This was supported by the fact that the proportion of monocotyledonsdicotyledons, compared to other forage consumed by the pampas deer, varies throughout the year. In winter and spring animals ingested more graminioid species and less dicotyledons (a typical grazing behavior), and the amount of dicotyledons ingested increases in autumn, and even more in summer. 
However, although the morphology is typical for browsers [length ratio between the small and the large intestine is 1:1.9 (Pérez et al. 2008)], the species' ingests large quantity of grass in its natural diet (HofmanN 1989).

In other ruminants there are differences in the relative size of the different compartments of the stomach. In Cervus nipon (Temminck, 1838), the omasum and the abomasum are larger in males than in females, although there are no differences in the size of the reticulum-rumen (RR) (JIANG et al. 2006). In the Odocoileus virginianus (Zimmermann, 1780) deer, the rumen is larger in lactating females than in non-lactating females or males (JENKs et al. 1994). According to BARBOzA \& Bowyer (2000), while male deer are better adapted for ruminal dominant digestion, females are better adapted for a post-ruminal dominant digestion.

To our knowledge, there is no available information on the macroscopic anatomy of the stomach of the pampas deer. The aim of this study was to describe the stomachs of fourteen pampas deer, including a size comparison in relation to gender. Data for size were compared with published data from other wild ruminants (including both cervids and bovid species).

\section{MATERIAL AND METHODS}

Fourteen deceased adult O. bezoarticus of both sexes from a captive breeding station [Estación de Cría de Fauna Autóctona Cerro Pan de Azúcar (ECFA), Piriápolis, Maldonado, Uruguay, $34^{\circ} 3^{\prime} \mathrm{S}, 55^{\circ} 1^{\prime} \mathrm{W}$, altitude: $\sim 200 \mathrm{~m}$ ] were used for this study. In the ECFA, which is also a tourist attraction, animals are bred for conservation purposes. Animals were allocated in 0.5-1 ha paddocks, in groups composed of 1 male and 5-8 females, or only 4-6 males. Animals grazed over native pastures, having free access to trees located in their enclosures, and each deer received approximately $600 \mathrm{~g}$ of dairy cow food rations daily. According to the manufacturer, the ration was composed by $16 \%$ crude protein and 12\% fiber (Molino San José, San José, Uruguay). This amount of food was supplied from Monday to Saturday throughout the year, and if part of the ration remained after feeding, this amount was considered ad libitum.

Animals used for this study appeared to have died of natural causes at the ECFA at various times throughout the year, though the cause of death was not determined. However, the corpses were in good condition, and death was not attributed to diseases that could affect the digestive tract. Mean body mass of males $(\mathrm{n}=5)$ was $15.0 \pm 3.4 \mathrm{~kg}$ (range $11.0-18.8 \mathrm{~kg}$ ) and that of females $(\mathrm{n}=9)$ was $14.5 \pm 2.4 \mathrm{~kg}$ (range 12.0-19.0 kg).

Animals were dissected fresh immediately after being found, or frozen for later dissection. The ventral abdominal wall of each animal was removed. The stomach was removed after sectioning the esophagus just cranial to the cardia, and pylorus adjacent to the duodenum. Stomach contents were measured by weighing the unopened organ with an electronic scale, and then re-weighing it after it had been opened, rinsed with tap water, and dried with paper towels. In the case of the ruminoreticulum, the empty organ was only weighed in two animals. Measurements of the RR followed Hofmann (1973): briefly, the RR was placed on its left side, and the height and length of the rumen and the reticulum, the length of the Curvatura omasi was measured with soft measuring tape. After the stomach compartments were emptied, the dimensions of the Ostia intraruminale, ruminoreticulare and reticuloomasale were measured with measuring tape. The thickness of the cranial and caudal rumen pillars, the maximum height of the reticular crests and the length of the Papillae unguiculiformes were measured with calipers. Pictures were taken with a digital camera. For a comparison with other literature data, we followed the approach of Clauss et al. (2006a, 2009a) by plotting the results of this study against data from other ruminant species. Terms are used in agreement with the Nomina Anatomica Veterinaria (2005). Male and female data were compared with ANOVA, and data are presented as mean \pm standard deviation.

\section{RESULTS}

The stomach of the pampas deer was composed of the four classic compartments found in ruminants (Fig. 1). There were no differences in the absolute or relative sizes of the different compartments with respect to gender (Tab. I).

A dorsal part of the rumen adhered to the diaphragm and sublumbar region. The weight of the entire full stomach was $2,068 \pm 739 \mathrm{~g}$. The full RR mass was $1,936 \pm 722 \mathrm{~g}$. In one male (BM $18.8 \mathrm{~kg}$ ) and one female (BM $13.0 \mathrm{~kg}$ ) in which the actual RR content mass was determined, it was 1,952 and 988 g or 10.4 and $7.6 \% \mathrm{BM}$, respectively. Lengths of the dorsal and ventral sacs were $27.5 \pm 3.7 \mathrm{~cm}$ (range 19 to $35 \mathrm{~cm}$ ) and $23.3 \pm$ $4.9 \mathrm{~cm}$ (range 16 to $37 \mathrm{~cm}$ ), respectively. The height of the rumen was $29.2 \pm 4.2 \mathrm{~cm}$. The Saccus caecus caudoventralis extended $2.5 \mathrm{~cm}$ more caudally than the Saccus caecus caudodorsalis (Fig. 1). The dorsal sac communicated with the ventral sac by the Ostium intraruminale, whose border was formed by the ruminal pillars, and which measured between $8.5 \times 8.5$ and $20 \mathrm{x}$ $15 \mathrm{~cm}$. The ruminal pillar thickness was $6.2 \pm 1.3 \mathrm{~mm}$ (range 4 to $9 \mathrm{~mm}$ ) and $6.7 \pm 1.8 \mathrm{~mm}$ (range 5 to $10 \mathrm{~mm}$ ) for the cranial and caudal pillars, respectively. The Ostium ruminoreticulare measured between $3.5 \times 4$ and $9 \times 6 \mathrm{~cm}$.

The ruminal papillae were more abundant within the atrium (Fig. 2), the ventral sac, and in the blind sacs than in other parts of the rumen. The papillae were almost absent in the dorsal sac (Fig. 3). The ruminal pillars had no papillae (Fig. 2). The reticulum (Fig. 4) was the third largest compartment, and its external measures were $9.8 \pm 2.6 \mathrm{~cm}$ in height, and 8.4 $\pm 1.9 \mathrm{~cm}$ in the craniocaudal length. The maximum height of the Cristae reticuli was $0.6 \mathrm{~mm}$. The Cellulae reticuli (cells) were not divided and rarely contained secondary crests. They were broader and deeper near the greater curvature and became smaller toward the lesser curvature. All crests had conical pa- 

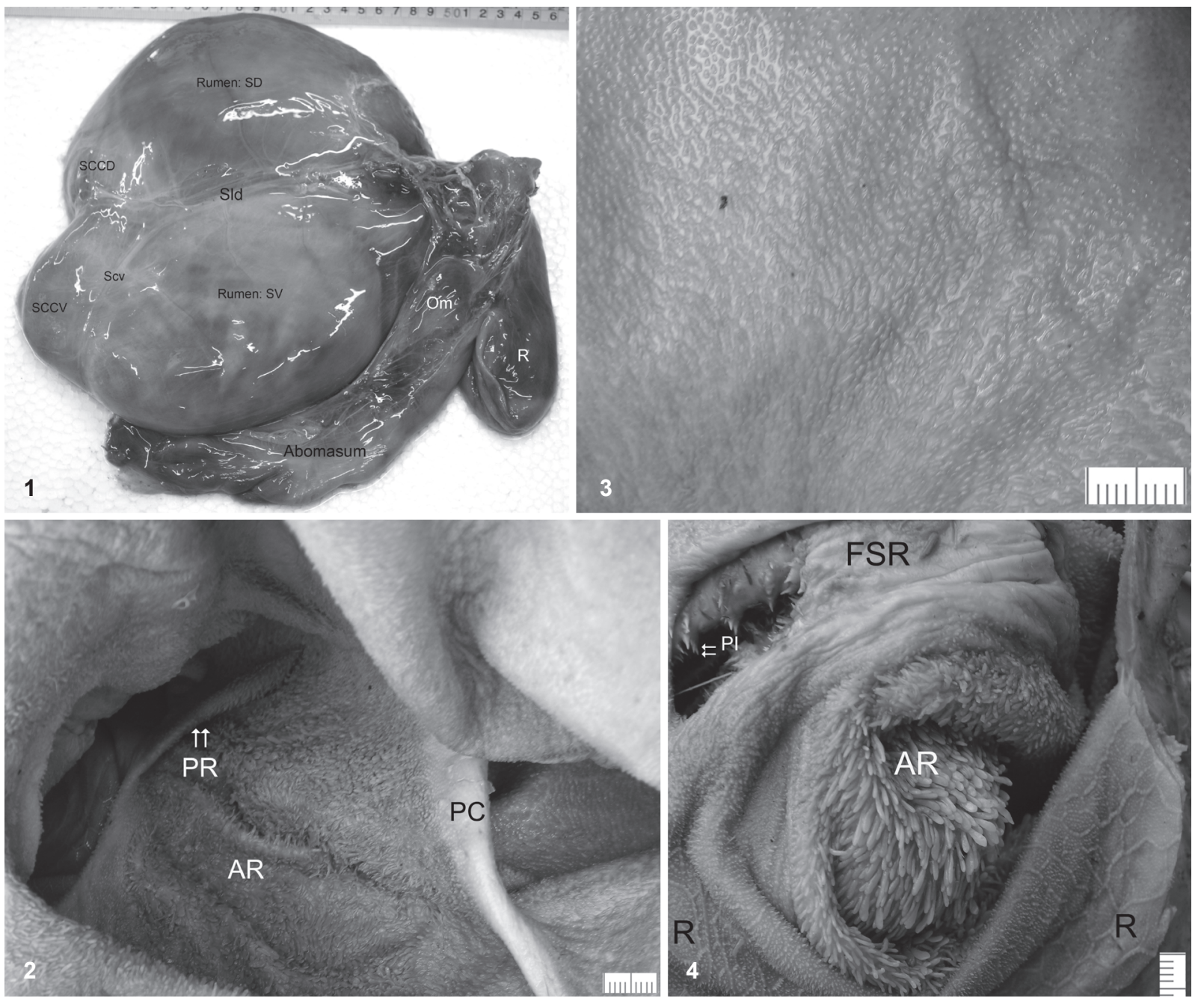

Figures 1-4. Ozotoceros bezoarticus: (1) right view of the stomach; (2) internal cranial view of the rumen; (3) internal view of the Saccus dorsalis of the rumen, note the absence of papillae; (4) internal view of the rumen and reticulum, note the large papillae. (AR) Atrium ruminis, (FSR) Fundus sulci reticuli, (Om) Omasum, (PC) Pila cranialis, (PI) Papillae unguiculiformes, (PR) Plica ruminoreticularis, (R) Reticulum, (SCCD) Saccus caecus caudodorsalis, (SCCV) Saccus caecus caudoventralis, (Scv) Sulcus coronarius ventralis, (SD) Saccus dorsalis, (SId) Sulcus longitudinalis Dexter, (SV) Saccus ventralis.

Table I. Stomach weight measurements in male and female pampas deer.

\begin{tabular}{lccc}
\hline & Male $(\mathrm{n}=5)$ & Female $(\mathrm{n}=9)$ & $\mathrm{p}$ \\
\hline Body weight $(\mathrm{kg})$ & $15.0 \pm 3.4$ & $14.5 \pm 2.4$ & 0.75 \\
Stomach weight (full) (g) & $1806 \pm 622$ & $2214 \pm 792$ & 0.34 \\
Stomach/Body weight ratio & $0.12 \pm 0.02$ & $0.15 \pm 0.04$ & 0.13 \\
Weight of the reticulorumen(full) (g) & $1671 \pm 561$ & $2084 \pm 788$ & 0.32 \\
Reticulorumen/Stomach weight ratio & $0.93 \pm 0.02$ & $0.93 \pm 0.02$ & 0.54 \\
Abomasum weight (g) & $105 \pm 52$ & $102 \pm 27$ & 0.93 \\
Abomasum/Stomach weight ratio & $0.06 \pm 0.01$ & $0.05 \pm 0.02$ & 0.68 \\
Omasum weight (g) & $31.0 \pm 16.5$ & $26.9 \pm 9.5$ & 0.56 \\
Omasum/Stomach weight ratio & $0.016 \pm 0.006$ & $0.013 \pm 0.006$ & 0.34 \\
\hline
\end{tabular}


pillae at the free border. The bottom of the cells had papillae of variable sizes. The fundus of the Sulcus reticuli was bordered by two thick protruding lips, devoid of papillae (Fig. 4). Near the Ostium reticulo-omasicum, the Papillae unguiculiformes had a length of about $1.0 \mathrm{~mm}$ (Fig. 4). The reticulo-omasal orifice measured $21.2 \pm 7.2 \mathrm{~mm}$ (range 14 to $40 \mathrm{~mm}$ ) in diameter.

The omasum was the smallest gastric compartment. The Curvatura omasi measured $11.2 \pm 3.1 \mathrm{~cm}$ (range 5.0 to $17.0 \mathrm{~cm}$ ). There were 10 primary Laminae omasi, 16 secondary lamellae, and small tertiary lamellae represented by small lineal elevations. The sides of the Laminae omasi were marked by the presence of the Papillae omasi that were,slightly more developed than the papillae of the reticulum. The abomasum had about 12 Plicae spirales abomasi, and a small Torus pyloricus was present.

\section{DISCUSSION}

To the best of our knowledge, this is the first anatomical description of the stomach of the pampas deer. An important limitation of this study is the fact that animals were not free- ranging and their diet was supplemented with dairy cow food rations, which possibly diminished forage intake. Therefore, measurements made in this study must be cautiously considered. In particular, the forestomach and the development of the omasum could have been influenced by the amount of roughage used to supplement their natural diet (Fluharty et al. 1999, Mcclure et al. 2000, Mcleod \& Baldwin 2000, Clauss et al. 2006b).

Although it should be cautiously considered due to the small number of animals measured, data on RR contents weighed in the two individuals in this study corroborate the perception of the pampas deer as a browser or an intermediate feeder (Fig. 5). Average measurements on rumen pillar thickness (Fig. 6), reticular crest height (Fig. 7), and the Curvatura omasi (Fig. 8) are all within the range observed in browsers or intermediate feeders. Keeping in mind the supplemental ration feeding and the subsequent small ingestion of grass, the RR fill and the size of the omasum are probably lower than that of wild specimens. These data could nevertheless be considered as belonging to an "intermediate feeder" classification. However, we concede that, given the reports on the natural
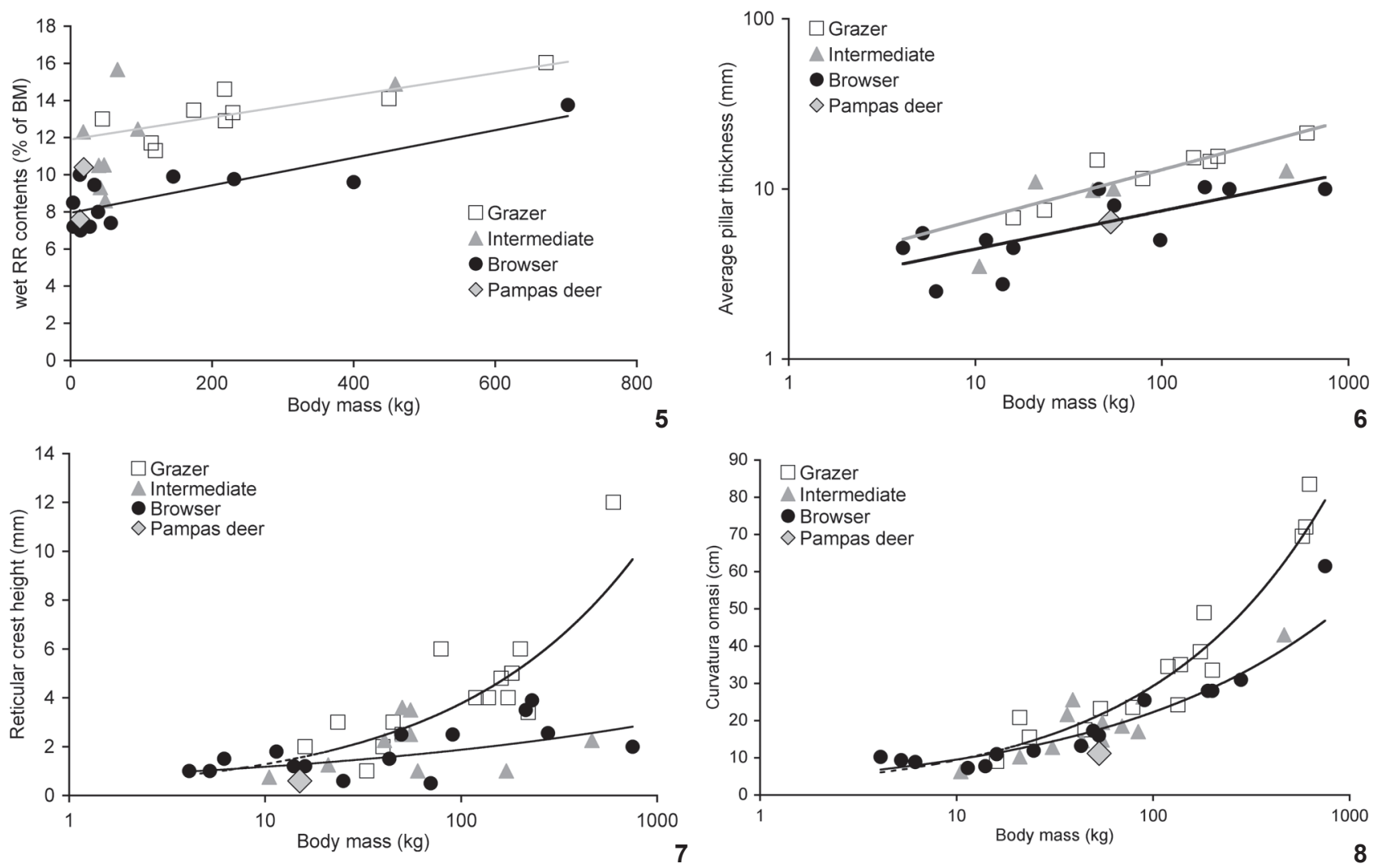

Figures 5-8. Comparison of data from Pampas deer from this study with data on (5) reticulorumen wet contents (in percentage of body mass) and (6) rumen pillar thickness (both from CLAuss et al. 2003, 2006a, 2009a), (7) reticular crest height (CLAuss et al. 2010), and (8) the curvature of the omasum (CLAuss et al. 2006ab, 2009a). Regression lines for browsing ruminants in inferior line and for grazing ruminants in superior line.

ZOOLOGIA 29 (4): 337-342, August, 2012 
diet of pampas deer (Rodrigues \& MonTeiro-Filho 1996, Cosse et al. 2009), the low values for the different measures depicted in Figs 6-8 are somewhat surprising. This discrepancy indicates that such anatomical measures alone cannot be considered sufficient for a classification of a ruminant species into a specific feeding type. Actual observations on the feeding behavior in the wild are required. Similarly, in a previous description (Pérez et al. 2008) the ration of small intestine to large intestine of pampas deer was within the range considered typical for browsers by HOFMANN (1989).

With respect to intraruminal papillation, a constant provision with a compound feed could be expected to lead to a rather homogenous papillation pattern. The fact that we could observe differences in the papillation between the dorsal rumen and the Atrium ruminis (Figs 3 and 4) indicates that the RR physiology of pampas deer is not similar to browser ruminants with a homogenous intraruminal papillation (Clauss et al. 2009b) and homogenous/unstratified RR contents (Clauss et al. 2010b). Thus, the papillation pattern of the RR is the only real correlate in the present study that fits the description of an adaptation to a large proportion of monocot material in the natural diet of pampas deer. Pampas deer most likely evolved a certain degree of RR fluid throughput and RR contents stratification typical for many intermediate feeder and grazing species. The correlation with various physiological measures (Clauss et al. 2009b, Codron \& Clauss 2010) implies that the intraruminal papillation pattern may be the most important comparative anatomical indicator between ruminant feeding types.

There were no differences in relation to gender. This can also be related to the feeding management, in which all animals were allowed access to sufficient amounts of food without competition or invoking hierarchical social interactions with regards to feeding. Therefore, the free access to food may mask possible anatomical differences between sexes that may be provoked by differences in food consumption.

To conclude, the anatomy of the forestomach of pampas deer is not in complete agreement with reports on its natural feeding habits. Similarly, Clauss et al. (2009c) listed several examples of ruminants with typical 'grazer' morphology that ingest more browser material in their natural diet than expected from anatomical observations alone. Pampas deer feed on a range of mixed diets in the wild Cosse et al. (2009). In particular, the size of the omasum can be suspected to be larger in free-ranging individuals. Discrepancies between the natural diet and the expected anatomical characteristics in the forestomach emphasize the evolutionary flexibility of the ruminant digestive system.

\section{ACKNOWLEDGEMENTS}

We thank Marcus Clauss (University of Zurich, Clinic for Zoo Animals, Exotic Pets and Wildlife) for support in designing the graphs and the discussion section of this paper. Brooke Hopkins Dubansky helped with language revision. Authors acknowledge Solana González and Matías Villagrán for their help collecting dead animals; Uruguay Tabaré González-Sierra, past Director of the ECFA, and the Intendencia Departamental de Maldonado, for the facilities to develop research at the ECFA. Financial support: CIDEC (Facultad de Veterinaria, Uruguay), CSIC (Universidad de la República, Uruguay) and Intendencia Departamental de Maldonado.

\section{LITERATURE CITED}

BARboza, P.S. \& R.T. Bowyer. 2000. Sexual segregation dimorphic deer: a new gastrocentric hypothesis. Journal of Mammalogy 81: 473-489.

Clauss, M.; M. Lechner-Doll \& W.J. Streich. 2003. Ruminant diversification as an adaptation to the physicomechanical characteristics of forage. A reevaluation of an old debate and a new hypothesis. Oikos 102: 253-262. doi: 10.1034/ j.1600-0706.2003.12406.x

Clauss, M.; J. Hummel; J. Völlm; A. Lorenz \& R.R. Hofmann. 2006 a. The allocation of a ruminant feeding type to the okapi (Okapia johnstoni) on the basis of morphological parameters, p. 253-270. In: A. Fidgett; M. Clauss; K. Eulenberger; J.M. Hatt; I. Hume; G. JansSens \& J. Nijboer (Eds). Zoo animal nutrition. Fürth, Filander Verlag, vol. 3.

Clauss, M.; R.R. Hofmann; J. Hummel; J. Adamczewski; K. Nygren; C. Pitra \& S. Reese. 2006b. The macroscopic anatomy of the omasum of free-ranging moose (Alces alces) and muskoxen (Ovibos moschatus) and a comparison of the omasal laminal surface area in 34 ruminant species. Journal of Zoology 270: 346-358. doi: 10.1111/j.1469-7998.2006.00148.x

Clauss, M.; S. Reese \& K. Eulenberger. 2009a. Macroscopic digestive anatomy of a captive lowland anoa (Bubalus depressicornis), p. 255-263. In: M. Clauss; A.L. FidgetT; J.M. Hatt; T. Huisman; J. Hummel; G. Janssen; J. Nijboer \& A. Plowman (Eds). Zoo animal nutrition. Fürth, Filander Verlag, vol. 4.

Clauss, M.; R.R. Hofmann; J. Fickel; W.J. Streich; J. Hummel \& G.W. Foundation. 2009b. The intraruminal papillation gradient in wild ruminants of different feeding types: Implications for rumen physiology. Journal of Morphology 270: 929-942. doi: 10.1002/jmor.10729

Clauss, M.; J. Adamczewski \& R.R. Hofmann. 2009c. Surface enlargement in the rumen of free-ranging muskoxen (Ovibos moschatus). European Journal of Wildlife Research 56: 181185. doi: 10.1007/s10344-009-0301-4

Clauss, M.; R.R. Hofmann; W.J. Streich; J. Fickel \& J. Hummel. 2010a. Convergence in the macroscopic anatomy of the reticulum in wild ruminant species of different feeding types and a new resulting hypothesis on reticular function. Journal of Zoology 281: 12-25. doi: 10.1111/j.1469. 7998.2009.00675.x

Clauss, M.; I.D. Hume \& J. Hummel. 2010b. Evolutionary adaptations of ruminants and their potential relevance for modern production systems. Animal 4: 979-992. doi:10.1017/S1751731110000388 
Codron, D. \& M. Clauss. 2010. Rumen physiology constrains diet niche: linking digestive physiology and food selection across wild ruminant species. Canadian Journal of Zoology 88: 1129-1138. doi: 10.1139/Z10-077

Cosse, M.; S. González \& M. Gimenez-Dixon. 2009. Feeding ecology of Ozotoceros bezoarticus: conservation implications in Uruguay. Iheringia Série Zoologia 99: 158-164. doi: 10.1590/S0073-47212009000200007

Fluharty, F.L.; K.E. Mcclure; M.B. Solomon; D.D. Clevenger \& G.D. LowE. 1999. Energy source and ionophore supplementation effects on lamb growth, carcass characteristics, visceral organ mass, diet digestibility, and nitrogen metabolism. Journal of Animal Science 77: 816-823.

Gonzalez, S. \& M.L. Merino. 2008. Ozotoceros bezoarticus. In: IUCN 2011. IUCN Red List of Threatened Species. Version 2011.1. Available online at: www.iucnredlist.org [Accessed: 2/VI/2012].

Hofmann, R.R. 1973. The ruminant stomach. Nairobi, East African Literature Bureau.

Hofmann, R.R. 1985. Digestive physiology of the deer - their morphophysiological specialisation and adaptation. Royal Society of New Zealand Bulletin 22: 393-407.

Hofmann, R.R. 1988. Morphophysiological evolutionary adaptations of the ruminant digestive system, p. 1-20. In: A. Dobson \& M. Dobson (Eds). Aspects of digestive physiology in ruminants. Ithaca, Cornell University Press.

Hofmann, R.R. 1989. Evolutionary steps of ecophysiological adaptation and diversification of ruminants: a comparative view of their digestive system. Oecologia 78: 443-457.

Hofmann, R.R. \& D.R.M. Stewart. 1972. Grazers and browsers: a classification based on the stomach structure and feeding habits of East African ruminants. Mammalia 36:226-240.

JaCkson, J.E. \& A. LANGGuth. 1987. Ecology and status of pampas deer (Ozotoceros bezoarticus) in the Argentinian pampas and Uruguay, p. 402-409. In: C. Wemmer (Ed.). Biology and management of the Cervidae. Washington, D.C., Smithsonian Institution Press.

Jackson, J. \& J. Giullietr. 1988. The food habits of pampas deer
Ozotoceros bezoarticus celer in relation to its conservation in relict natural grassland in Argentina. Biology of Conservation 45: 1-10. doi:/10.1016/0006-3207(88)90048-1

JACKSON, J.E.; A. LANGgUTH \& P. LANDA. 1980. The pampas deer in Uruguay. Oryx 15: 267-272.

Jenks, J. A.;, D.M. Leslie; R.L. Lochmiller \& A. Melchiors. 1994. Variation in gastrointestinal characteristics of male and female white-tailed deer: implications for resource partitioning. Journal of Mammalogy 75: 1045-1053.

Jiang, Z.; S. Hamasaki; H. Ueda; M. Kitahara; S. Takatsuki \& M. Kisнiмото. 2006. Sexual variations in food quality and gastrointestinal features of Sika Deer (Cervus Nippon) in Japan during winter: implications for feeding strategy. Zoological Science 23: 543-548.

Jungius, H. 1976. Status and distribution of threatened deer species in South America. World Wildlife Yearbook. Morges, World Wildlife Fund.

Mcclure, K.E.; M.B. Solomon \& S.C. Loerch. 2000. Body weight and tissue gain in lambs fed an all- concentrate diet and implanted with trenbolone acetate or grazed on alfafa. Journal of Animal Science 78: 1117-1124.

Mcleod, K.R. \& R.L. BALDWin. 2000. Effects of diet forage: concentrate ratio and metabolizable energy intake on visceral organ growth and in vitro oxidative capacity of gut tissues in sheep. Journal of Animal Science 78: 760-770.

Nomina Anatomica Veterinaria. 2005. 5th ed. International Committee on Veterinary Gross Anatomical Nomenclature (I.C.V.G.A.N.). Available online at: www.wava-amav.org/ Downloads/nav_2005.pdf [Accessed: 02.VI.2012.]

Pérez, W.; M. Clauss \& R. Ungerfeld. 2008. Observations on the macroscopic anatomy of the intestinal tract and its mesenteric folds in the pampas deer (Ozotoceros bezoarticus). Anatomia Histologia Embryologia 37: 317-321. doi: 10.1111/j.1439-0264.2008.00855.x

Rodrigues, F.H.G. \& E.L.A. Monteiro-Filho. 1999. Feeding Behavior of the Pampas Deer: A Grazer or a Browser?. Deer Specialist Group News 15: 12.

Submitted: 13.XII.2011; Accepted: 06.VI.2012.

Editorial responsibility: Carolina Arruda Freire 